\title{
DEVELOPING AND IMPLEMENTING COMPREHENSIVE STUDENT SUPPORT SERVICES FOR ONLINE STUDENTS
}

\author{
Marwin Britto \\ Susan Rush \\ Lone Star College System
}

\begin{abstract}
Student retention in higher education has become a critical focus in recent years. This paper describes the efforts of Lone Star College-Online and its Online Student Support Services unit to build and implement a comprehensive suite of services for online students with the intention of enhancing the online student experience and ultimately, directly and indirectly, improving student retention rates. It is hoped that others can learn and gain from the shared successes and challenges presented in this paper.
\end{abstract}

\section{KEYWORDS}

Support services, retention

\section{INTRODUCTION}

In the United States, the annual student enrollment growth rate for higher education institutions has slowed considerably over the past few years. Specifically, in the Fall term of 2008, 2009 and 2010, the student enrollment growth was 4.7 percent, 2.2 percent, and 0.6 percent, respectively [1]. For the past decade, the annual growth rate in online student enrollment in higher education institutions in the United States has been significantly higher than overall growth in higher education. Specifically, in the Fall academic terms of 2008, 2009 and 2010, the annual online student enrollment growth rate across U.S. higher education institutions was 16.9 percent, 21.1 percent and 10.1 percent, respectively [1]. In 2010, thirty-one percent of all higher education students were taking at least one course online representing over 6.1 million students and an increase of 560,000 students over the previous year.

Unfortunately, the strong growth record of student enrollment in online courses has been overshadowed by course dropout and failure rates among online learners which have been higher than campus-based rates since the emergence of online courses 20 years ago [2, 3, 4, 5, 6, 7]. In addition, some studies have found that students in online courses at community colleges, who are often non-traditional and/or from lower socioeconomic levels than students at four-year institutions, have lower completion rates and higher failure rates than online students at four-year institutions [8].

\section{DEFINITIONS}

A critical focus in higher education institutions today is on student retention. Retention has been a primary driver for many institutional student services initiatives.

This paper describes Lone Star College-Online and Online Student Support Services' initiatives. It is important at the outset to define the term "student retention" and related terms. A common definition of the term "student retention" remains elusive and varies depending on the type of institution, the context and the intention [9]. For purposes of this paper, Crawford's [10] definition of community college student program retention works well. According to Crawford, student retention is "...maintenance of continued enrollment for two or more semesters, specifically from Fall term to Spring term and/or completion of a degree/certification or transfer to a four-year college" (p. 13). Two sub- 
groups of student retention rates are particularly important in this discussion---"student course completion" and "student course success" rates. Although these definitions may also vary by institution, generally speaking and at Lone Star College System, "student course completion" rates can be defined as the percentage of students enrolled in a course that do not withdraw, but finish the course and receive a final grade. "Student course success" rate is the percentage of students enrolled in a course who not only finish the course, but receive a final letter grade (or equivalent) of "A", "B" or "C".

\section{REVIEW OF LITERATURE}

\section{A. Retention Rates}

Poor retention rates have a negative impact on the institution's and students' financial resources, as well as on the local economy. It is estimated that a 1 percent improvement in graduation and completion rates for higher education institutions in the Houston region would boost personal income in the area by $\$ 4.2$ billion annually [11]. Institutions have a vested interest in ensuring that students graduate because institutions invest resources, financial and otherwise, into recruiting and admitting students. Students, too, have a lot to lose if they withdraw without completing their academic degree. Many students take out hefty student loans to attend higher education, but without degree completion, their chances of acquiring gainful employment and paying back the loan diminish. In addition, if the students receive federal financial aid assistance and withdraw early in the term, they are legally required to return a portion of the aid received, although it may have already been spent.

Accreditation agencies place further pressure on improving these numbers as they perceive completion rates as a measure of institutional effectiveness, educational rigor and quality [12]. The cost of an institution receiving probationary accreditation status or losing institutional accreditation altogether as a result of poor completion rates in courses can tarnish the institution's reputation [13], impact future student enrollment, and subsequently, institutional financial stability. Poor accreditation status can lead to further financial implications because most federal student loan programs are contingent on an institution maintaining proper accreditation status.

The most recent research indicates that the completion and success rates for higher education students enrolled in online courses continues to be far lower than students in face-to-face courses [14] with a gap in retention rates at some institutions as high as 20 percent [15] and dropout rates as much as six to seven times higher in online courses than in campus-based courses [16]. These reports are based on individual institutions or consortia, since no national trending data is currently available.

\section{B. Why Online Courses?}

Students flock to higher education online courses for a variety of reasons. The Noel-Levitz National Priorities Online Learners Priorities Report [17] finds that the top three reasons students select online courses are convenience, flexible programming, and compatibility with their work schedules. Conversely, there are a host of reasons why students withdraw from online courses or perform poorly in them. Some are within the locus of institutional control, while many are beyond an institution's purview.

In their study, Yukselturk and Inan [18] found online students drop out for three reasons; affordability, personal problems, and insufficient time to study. Moore et al. [19] discovered six factors negatively influencing student retention were: a large course load, a lack of experience in higher education, a lack of experience with online courses, busy lives outside of coursework, a young age, and a lack of access to technology and computers. Family and work obligations are also widely cited in the literature as primary reasons for student attrition in online courses [20, 19].

Within the context of the online course, student retention is impacted by the quality of interaction between faculty and students in an online course [21]; current, interesting and relevant course feedback; timely feedback from faculty; and an interactive learning environment $[22,23]$. These factors have been cited as important for retaining online students. In addition, numerous studies provide evidence that 
Developing and Implementing Comprehensive Student Support Services for Online Students

faculty training, assessment strategies, pedagogical course design, social structures, and opportunities for student engagement and collaboration can have a positive impact on student retention [20, 24, 25].

\section{Retention Strategies}

Over the past two decades, institutions of higher education have employed a multitude of student retention strategies with varying degrees of success. This section highlights a number of these strategies.

\section{Campus Orientation for Online Students}

Many traditional institutions offer a student orientation for face-to-face students to get them familiar with the setting, processes, schedules, deadlines, etc. and to ultimately help them successfully transition to higher education. Similarly, offering online students an orientation to the institution has demonstrated that it can boost their confidence levels, give them a sense of belonging and community, help them learn the technology and prepare them for the online learning context, connect them with peers and instructors, and tends to reduce the number of technical problems online students normally have [26, 27]. This orientation might provide online students complete information on how to access student services within the institution.

Student support services for online students are often not integrated with the total student experience, which often leads to frustration and subsequent withdrawal from courses [6, 28, 21]. Heyman [21] reports that the greatest factors in student retention are student support and student connections to the institution. Departments that provide ongoing student services to face-to-face students, such as admissions, financial aid, registration, the library, tutoring, and academic advising, should also make services fully available and accessible to online students [29, 30]. Furthermore, it is good practice to adequately train staff members in these departments to understand the unique context and specific needs of the online student population, and resources and services should be modified and customized to meet their needs.

\section{Online Student Orientation}

First and foremost, it is helpful to inform online students of the basic technical skills needed, and necessary hardware and software requirements; a basic guide or manual is often useful in this regard [31, 32]. This information is often embedded within the context of a student online orientation. An online orientation familiarizing students with the online course learning environment is one of the greatest factors in predicting a student's success in an online course [33, 7]. Students, too, report that an orientation to the course context is a critical support structure at the beginning of their course [34]. The orientation can be designed to be interactive, introduce students to the type of assignments they will be required to complete, allow for the development of technical and computer skills, and help students develop appropriate NetEtiquette [35]. In addition, an effective student orientation for online students is best offered in the same environment - in this case, the Learning Management System - and with the same tools and resources as available in the online course, so the student can experience and experiment with the environment authentically; an assessment should be employed to ensure the student has mastered the necessary knowledge and skills to succeed in the online course [20,36].

\section{Online Student Readiness Assessment}

Not all students are prepared to take courses online. An assessment of their potential for success can be measured through "online student readiness" instruments. Institutions take a variety of approaches in using these...some offer them as a freely available and optional resource on their website, others embed them within an orientation course as described previously, and still others require it as one of the first assignments in an online course. These self-assessments generally provide students cautions identifying deficiencies and acknowledging strengths [37]. According to Mercer and Simmons [38], 30 percent of institutions make it mandatory for new students to take this type of online readiness assessment. 


\section{Help Desk for Technical Support for Online Students}

Providing adequate technical support is critical to the success of online students [39]. Accordingly, a student "help desk" for technical support via phone, email and chat is an essential support resource. For most institutions, support for online students is usually an extension of support services for face-to-face students. But extending support does require providing targeted information for online students, such as tutorials, FAQs, and special training for help desk staff to learn the specific issues and resolutions for online students [40]. In addition, it is beneficial to establish a single point of contact for the help desk so online students know how and whom to contact to have their problems addressed [41].

Since online students may experience problems beyond normal business hours, it is beneficial to offer live technical support in off-hours. Although most institutions have some sort of help desk for online students, what varies is the availability of support hours. Figure 1 below captured from the 2010 Managing Online Education Survey [42] shows that in the Fall academic term of 2010 about a third of institutions offering a technical support help desk for online students provided it 24 hours/7 days a week, another third during weekdays, evenings and limited weekends, and about 15 percent during regular work hours (e.g., weekdays, Monday-Friday, $9 \mathrm{am}-5 \mathrm{pm}$ ). The remaining 20 percent offered support during weekends and limited evenings. What is not known is the impact that these hours have on online student completion and success rates. That is, do higher education institutions offering a 24/7 technical support service for online students have higher online student completion and success rates when compared to those only offering these services to online students during regular work hours?

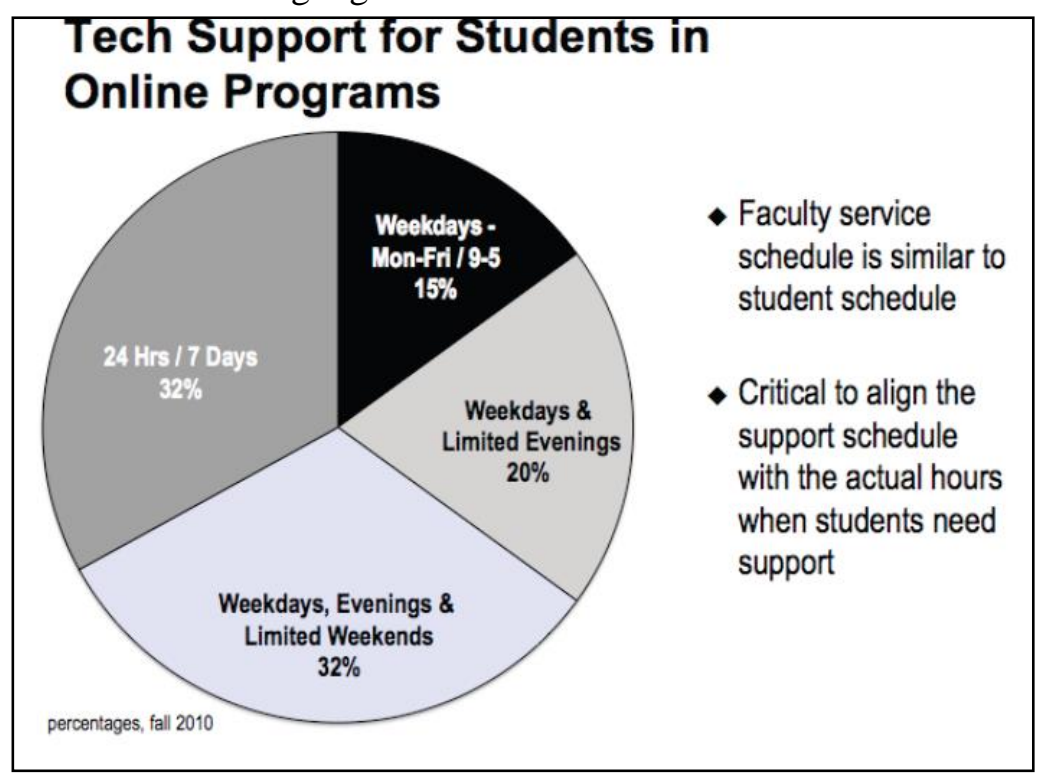

Figure 1. Technical Support Availability for Students in Online Courses

\section{Institution-Wide Approaches to Student Retention}

Nitsch [43] suggests that student retention is best approached by addressing three distinct areas: 1. personal attributes related to the students' cognitive, affective and psychological behaviors, 2 . instructors' (and instructional designers') role in designing and delivering an interactive, relevant and engaging curriculum, and 3. curriculum, student support services, academic policies and procedures, and technological access that are student-centered. Others suggest institution-wide student retention plans that focus on institutional philosophy and on process and procedures have the best chance of success [9]. Consequently, a systemic and integrated institutional approach to addressing student retention would most likely pay the biggest dividends. Not surprisingly, as with most institutional plans, gaining cooperation, input and a concerted and coordinated effort from divisions dispersed across the institution with varying levels of interest, engagement and motivation, can be a most arduous task. 
Developing and Implementing Comprehensive Student Support Services for Online Students

Despite efforts to address student retention amidst the meteoric growth in online student enrollment, this problem still persists in many higher education institutions in the U.S. today [44, 45]. The literature suggests that there is no single "one-size-fits-all" strategy to consistently, systematically, and sustainably deal with this problem across all types of institutions. Nevertheless, the measured success of individual strategies does suggest a more integrated and comprehensive approach employing a combination of approaches might be the best option. Armed with this knowledge and belief, in 2011 Lone Star CollegeOnline and Online Student Support Services embarked on an ambitious journey to model such an approach. This paper describes Lone Star's efforts, successes and challenges.

\section{LONE STAR COLLEGE SYSTEM: PROVIDING ONLINE STUDENT SUPPORT SERVICES}

Located in the North Houston area, Texas, Lone Star College is a multi-campus community college system with six colleges, five campus centers, two university centers, and $11 \mathrm{~K}-12$ school districts serving students across 1,400 square miles in two counties. It offers certificates and associate's degree programs, and through its high school and university center partnerships, also offers high school diplomas, bachelor's, master's, and $\mathrm{PhD}$ degrees. Lone Star is the largest community college system in Houston, Texas and the fastest growing community college in the nation [46]. In 2012, Lone Star College System had its highest enrollment ever with 77, 877 credit students. The online student enrollment increased 21 percent from 2008 to 2009, 25 percent from 2009-2010, and 27 percent from 2010-2011. With a record total student enrollment of 90,000 (credit and non-credit) in the Fall term of 2012, online student enrollments also experienced a record enrollment with the number of students enrolled in online courses exceeding 28,850 .

\section{A. Lone Star College-Online}

Lone Star College-Online (LSC-Online) is a service and support department in the Lone Star College System providing support to online faculty and online students. The department is comprised of a staff of 32 professionals committed to the department's mission of innovation, leadership, and vision to support emerging technologies proven to enhance online learning. Lone Star College-Online serves 800+ online faculty teaching 28,000+ online students in 1,900 online courses each semester. In 2010, this department was comprised of two units: Course Development, and Faculty/Technology Support. In 2011, an Online Student Support Services groups became the third unit added to LSC-Online. Recent survey data indicated that there was a growing trend to decrease online student services in higher education [47]. Regardless, with record online student enrollment the past few years, Lone Star made a strategic decision to move in the opposite direction and invested long term funds and resources to launch the Online Student Support Services unit at the start of 2011. As the number of online students continued to increase, Lone Star College-Online wanted to ensure that it made a concerted effort to scale, improve, and continue to provide quality support and full services to its online students.

\section{B. Online Student Support Services}

The first step in launching the new Online Student Support Services unit was the hiring of a manager in January 2011, who began her job by developing a strategic plan for this new unit. From March-May 2011, two fulltime online advisers were hired. The initial focus for this unit was on three initiatives for three target populations: Early Alert Assistance for all online students (24,641 students) including those with face-to-face courses; Online Advising, for fully online students $(7,448)$, who did not have any faceto-face courses and consequently no access to a face-to-face adviser; and Case Management Advising, for First Time in College (FTIC) fully online students (316 students), who needed more support and guidance than other students.

With Early Alert Assistance, a commercial software program called Starfish integrated with the Learning Management System (LMS). Starfish automatically flagged and then alerted online students and the instructor (via email) if they had not logged into the LMS in five consecutive days (or any other 
predetermined period of time). For Online Advising, full advising services were provided to fully online students who did not have access to face-to-face advisers. In Case Management Advising, proactive and intrusive advising services were provided exclusively for the at-risk population of first time in college, fully online students. (Online Student Support Services introduced these three initiatives in phases with Early Alert Assistance piloted in June 2011, Online Advising in May 2011, and Case Management Advising in September 2011. In the Fall term of 2011, all three initiatives were operating concurrently.

\section{Goals}

The goals for the Comprehensive Online Student Support Services Model were two-fold: 1. to provide at least comparable services for online students and face-to-face students; and 2. to increase completion and success rates for online students to bring them on par with face-to-face student population. In the Fall term of 2011, completion and success rates (as defined earlier) at Lone Star College System were 86 and 77 percent for face-to-face students, 83 and 68 percent for online students, and 87 and 80 percent for hybrid students.

This gap between completion and success rates for online students and face-to-face students at Lone Star was generally smaller than those reported in the literature by other higher education institutions in the U.S. [15, 14]. Of course, there is always room for improvement, and the introduction of the Online Student Support Services unit in 2011 at Lone Star was an opportunity to further decrease this gap. It is interesting to note that the hybrid completion and success rates for students were superior to the online and face-to-face counterparts at Lone Star College System. This outcome is somewhat consistent with findings of other studies such as the longitudinal Distributed Learning Impact Evaluation [48] which demonstrated that retention rates for hybrid courses are frequently quite similar to face-to-face courses.

\section{Initiatives}

In addition to the initial three initiatives of Early Alert Assistance, Online Advising, and Case Management Advising launched in 2011, Online Student Support Services (and its parent department, Lone Star College-Online) also inherited a number of related services, which had been previously implemented by other departments. These included the Online Readiness Assessment, the Online Student Orientation, and Online Tutoring. One service, Technical Support, continued to be supported by the Technology Services group for general questions. However, questions directly related to topics within the Online Student Support Services' purview were now redirected to this unit. Furthermore, in 2012, two new initiatives were developed and launched by Online Student Support Services; namely, the New Student Orientation, and the E-Newsletter. Table 1 below summarizes the initiatives which Lone Star College-Online and Online Student Support Services have supported and/or developed, implemented, evaluated, and revised. A detailed description of each initiative follows the table in subsequent sections.

\begin{tabular}{|l|l|l|l|}
\hline Initiative & $\begin{array}{l}\text { Launch } \\
\text { Date }\end{array}$ & Target Population & Impact \\
\hline $\begin{array}{l}\text { Technical Support } \\
\text { (Optional) }\end{array}$ & $\begin{array}{l}\text { Prior to } \\
2011\end{array}$ & $\begin{array}{l}\text { All Online Students } \\
\text { (Fully online and } \\
\text { hybrid); } \\
26,184 \text { in Fall 2011 }\end{array}$ & $\begin{array}{l}\text { Increased technical support for all } \\
\text { LSCS students. }\end{array}$ \\
\hline $\begin{array}{l}\text { Early Alert System } \\
\text { (Required) }\end{array}$ & Fall 2011 & $\begin{array}{l}\text { All Students in Fully } \\
\text { Online Courses; } \\
22,449 \text { in Fall 2011 }\end{array}$ & $\begin{array}{l}\text { Improved communication between } \\
\text { students and advisers who may be } \\
\text { struggling; Increased communication } \\
\text { between advisers and online faculty }\end{array}$ \\
\hline $\begin{array}{l}\text { Advising Services } \\
\text { (Optional) }\end{array}$ & Fall 2011 & $\begin{array}{l}\text { Fully Online Students; } \\
7,448 \text { in Fall 2011 }\end{array}$ & $\begin{array}{l}\text { Increased access for fully online } \\
\text { students to academic advisers. }\end{array}$ \\
\hline Case Management & Fall 2011 & First Time in College & Increased assistance and access for \\
\hline
\end{tabular}


Developing and Implementing Comprehensive Student Support Services for Online Students

\begin{tabular}{|l|l|l|l|}
\hline $\begin{array}{l}\text { Advising } \\
\text { Required) }\end{array}$ & $\begin{array}{l}\text { (FTIC), Fully Online } \\
\text { Students; 316 in Fall } \\
2011\end{array}$ & $\begin{array}{l}\text { FTIC, fully online students throughout } \\
\text { their first semester in college. }\end{array}$ \\
\hline $\begin{array}{l}\text { Readiness } \\
\text { Assessment } \\
\text { (Optional) }\end{array}$ & $\begin{array}{l}\text { Prior to } \\
2011\end{array}$ & $\begin{array}{l}\text { All Students and non- } \\
\text { Students; } \\
90,000+\text { in Spring 2012 }\end{array}$ & $\begin{array}{l}\text { Provides an assessment that can help } \\
\text { students determine their level of } \\
\text { readiness for online courses. }\end{array}$ \\
\hline $\begin{array}{l}\text { Student Orientation } \\
\text { (Required) }\end{array}$ & $\begin{array}{l}\text { Prior to } \\
2011\end{array}$ & $\begin{array}{l}\text { All Online Students } \\
\text { (Fully online and } \\
\text { hybrid); } \\
29,368 \text { in Spring 2012 }\end{array}$ & $\begin{array}{l}\text { Increased student's knowledge and } \\
\text { comfort level with taking online } \\
\text { courses. }\end{array}$ \\
\hline $\begin{array}{l}\text { Tutoring } \\
\text { (Optional) }\end{array}$ & 2011 & $\begin{array}{l}\text { All Students in Fully } \\
\text { Online Courses; } \\
6,389 \text { in Fall 2011 }\end{array}$ & $\begin{array}{l}\text { Provides access to tutoring for all } \\
\text { students taking a fully online course } \\
\text { and who may be unable to access on } \\
\text { campus. }\end{array}$ \\
\hline $\begin{array}{l}\text { New Student } \\
\text { Orientation } \\
\text { (Required for all } \\
\begin{array}{l}\text { First Time in } \\
\text { College Students }\end{array}\end{array}$ & $\begin{array}{l}\text { Spring } \\
2012\end{array}$ & $\begin{array}{l}\text { First Time in College, } \\
\text { Fully Online Students; } \\
316 \text { in Fall 2011 }\end{array}$ & $\begin{array}{l}\text { Provides advising and registration } \\
\text { sessions for fully online students who } \\
\text { may be unable to come to campus. }\end{array}$ \\
\hline $\begin{array}{l}\text { E-Newsletter } \\
\text { (Optional) }\end{array}$ & $\begin{array}{l}\text { Summer } \\
2012\end{array}$ & $\begin{array}{l}\text { Fully Online Students; } \\
8,500 \text { in Summer 2012 }\end{array}$ & $\begin{array}{l}\text { Increased communication to fully } \\
\text { online students who are not on } \\
\text { campus. }\end{array}$ \\
\hline
\end{tabular}

Table 1. Summary of Online Student Support Services Initiatives

\section{a. Online Technical Support}

At Lone Star College System, online students have access to a 24/7 Technical Support Help Desk. Students enrolled in online courses can call a toll-free number, send an email or chat synchronously with a technician trained to provide them general technical support and assistance for challenges in their online courses. If the problem is very specific and can't be resolved by the tier 1 technician, it then gets escalated and routed to a tier 2 technologist from LSC-Online who is knowledgeable with issues related to online students. Questions related to student advising or other areas addressed by Online Student Support Services are directed to this unit.

\section{b. Early Alert System}

In 2011, Online Student Support Services implemented the use of Starfish, which is a commercial student retention tracking software program. Starfish provides the ability to: document/track all student communications; send out early alerts; create action plans for students; and allow online appointment scheduling for students. All chats are documented through Starfish where advisers can view the content of all prior chats with students. In addition, emails, phone calls, and video/audio conferencing advising sessions with students are also captured.

The Online Inactivity Early Alert Initiative was initially piloted during the Summer and Fall academic terms of 2011. Inactivity flags were configured so that all students taking online courses would receive an inactivity alert if they did not log into their course within 5 or 3 days (depending on the length of the course). The Online Student Support Services unit would also receive a copy of this flag. After the program sent an e-mail message to the student, the plan was to have an adviser contact the student within 24-48 hours if the student still had not logged into his/her course. Flags were not cleared until the student responded to the alert email. During the Fall term of 2011, Online Student Support Services received over 65,000 flags that were given to online students. 
Based upon this Early Alert pilot, the following adjustments were made: three additional advisers were hired to focus specifically on early alerts; the process of how flags were cleared was changed (i.e., flags were cleared once Online Student Support Services reached out to the student); and Online Student Support Services began to work with the department chairs to reduce the number of the courses using other programs outside of the Learning Management System in order to reduce "false" flags.

In Spring 2012, Online Student Support Services implemented a new General Inactivity Early Alert Process: Inactivity early alerts (email) go out to students if they have not logged into their course in 5 days (for a 9-16 week session) and 3 days (for a 1-8 week session); after receiving the alert, if the student has not logged into the online course within 24-48 hours, an online adviser would reach out to the student via email offering assistance; for students who appear high risk (i.e., multiple flags, low grades for semester and/or course history), an online adviser would call the student.

Through the early alert implementation and adjustments, the Online Student Support Services unit has seen some successes. Specifically, there has been an increase in outreach and communication to online students since students are able to communicate with advisers regarding any issue they may have (such as health problems, problems accessing textbooks, or financial problems); student have responded positively stating the reminders are helpful; there has been increased communication and collaboration between faculty and advisers, and the advisers and help desk have been able to assist students to resolve technical issues which enhances student success.

\section{c. Online Advising}

Lone Star College System's fully online students have access to an advising chat button within their Lone Star Student Portal. Fully online students are the only students who have this button visible. When students click on the button, it asks them to indicate their question. Their question is then routed to an online adviser for assistance. Online students can request assistance with any issue face-to-face students pose to their advisers, such as registration, transfer information, transcripts, degree plan overview, drop/add, online course information, etc. After a student clicks on the chat button, the system launches a text-based chat window in which the adviser and student can communicate. (An open source and free software program called Openfire is used for the back-end functionality, and Spark for the actual chat function). When the adviser receives the chat, the system automatically pulls in the student's name, primary campus, student ID, and indicates if the student is on Financial Aid and/or is a Veteran. At the end of the session, the student has the option of receiving a transcript of the chat. Online advising is also provided through email, phone and video/audio web conference (through a commercial software program called WebEx). From January 1, 2012 to May 13, 2012 (i.e. Spring Semester), 5,819 advising sessions were conducted: 3,278 through chat; 2,185 via email; 300 by phone; and 56 through WebEx.

The effectiveness of the advising sessions is important. Accordingly, at the end of every chat advising session, all students are provided the option to complete a confidential student satisfaction survey with three questions asking students to rate the adviser's performance in three areas. In Fall term of 2012, we extended the satisfaction surveys to include advising through other modalities beyond chat (i.e., phone, email and WebEx)). From May 5, 2011 to May 5, 2012, 6,293 chats were conducted and 333 completed surveys were received indicating a response rate of approximately 5 percent. For this one year period, the "Very Satisfied/Satisfied" rates of the students completing the surveys were very high: 90 percent for how well the adviser answered their question, 91 percent for the overall knowledge of their online adviser, and 97 percent with the ease in process to chat with an online adviser.

\section{d. Case Management Advising for First Time in College (FTIC) Fully Online Students}

The First Time in College (FTIC), fully online students are assigned a case management adviser during their first semester to cover the following critical activities: discussion of academic and career goals; development of an Academic Plan; discussion of financial aid and the financial aid process; review and referral to campus resources; referral to Career Counseling; and follow-up and preparation for the next semester. Case management advisers reach out to their cohort students multiple times throughout the semester. Typically they reach out to students a couple of times each month and provide information 
Developing and Implementing Comprehensive Student Support Services for Online Students

regarding student resources, general financial aid information, and reminders of important dates. They make appointments with their students in order to discuss their career and academic goals and then walk them through their Advising Report (degree plan) and the steps to create their "myPlanner", which allows students the ability to plan their course selections for the next two years.

\section{e. Online Student Readiness Assessment}

At Lone Star College System, Lone Star College-Online utilizes a commercial software program, the SmarterMeasure Learning Readiness Indicator, to give Lone Star students the opportunity and option to self-assess their potential for success in an online course. This web-based tool is accessible on Lone Star's website and accessible to all Lone Star College students. It allows students to use one generic name and password to take the assessment, and to provide their email address if they wish to directly receive the comprehensive results and/or have these results sent to an instructor.

Through a final report, the tool indicates the degree to which an individual student possesses attributes, skills, and knowledge that contribute to success including the areas of self-motivation; time-management skills; self-discipline; on-screen reading rate and recall; persistence; availability of time; ability to use a laptop, printer, software, and the Internet; and typing speed and accuracy. In addition, it provides resources to help support the areas in which students may be deficient.

From September 1, 2011 to September 1, 2012, 2,887 students completed SmarterMeasure. Unfortunately, since all students used the same generic name and password to access the tool, it is not known how effective it has been for students in determining their readiness for online courses, or if there was a positive correlation between a low score on this readiness indicator and poor completion or success rates in Lone Star's online courses. Accordingly, beginning in the Fall term of 2012, this SmarterMeasure tool was moved from the website and was integrated into the Lone Star Student Portal. This move removed the "anonymity factor" and allowed Online Student Support Services to track online students and scores by ID. There is discussion about making the completion of this survey a requirement for online students, but no final decision has been made as of October 2012. The intent of making it a requirement is for online students and the institution to better understand students' strengths and deficiencies in the online environment in order to provide them assistance in addressing any challenges they may have, and ultimately improve their likelihood of succeeding in their online courses.

\section{f. Online Student Orientation}

In the spring of 2010, a team of Lone Star College-Online instructional designers was tasked with designing Lone Star's Online Student Orientation, which would be required by all students taking online courses beginning in the Fall term of 2010. The goal of the orientation was to familiarize students with navigation and tools within the online learning environment in order to enhance their chances of success. To develop the orientation curriculum, the designers first consulted with peers at other institutions, with Lone Star administrators, faculty and students, and reviewed best practices in the literature. The primary source of the content was Paloff and Pratt's The Virtual Student [33], the Quality Matters rubric [49], as well as internal resources and materials from our institutional Disability Services and Lone Star CollegeOnline departments. At the end of this process, the designers determined the most appropriate topics to embed in the online orientation for online students.

The module topics and sequence for the orientation are: 1. Before You Begin; 2. earning Online; 3. Navigation; 4. Tools; 5. Communication; 6. Success Tips; 7. Support; 8. Pre-Quiz Summary; and 9. References. The Online Student Orientation takes approximately 45 minutes for students to complete, and students must achieve at least an 80 percent in the final assessment before they are permitted access to their online or hybrid course(s). Students who successfully complete the Online Student Orientation are waived from taking any further online orientations for three years. In 2011-2012 academic year, 28,853 students completed the orientation with an average grade of 86.2 percent in the assessment. Since the adoption of this online student orientation in the Fall term of 2010, 103,422 students have completed this orientation with an average grade of 86.6 percent in the orientation assessment. 


\section{g. Online Tutoring}

Through Online Tutoring, provided by a commercial product called Smarthinking, Online Student Support services offers free 24/7 online tutoring and instructional supplementation for students in fully online courses. The tutors are certified in the following subjects: Accounting, Biology, Chemistry/Organic Chemistry, Economics, Finance, Introductory Anatomy \& Physiology, Math/Bilingual Math, Physics, Spanish, Statistics, and Writing. Through Smarthinking, students can: connect with a tutor for a private session, schedule a personal session with a tutor, submit their writing, and receive feedback, and submit questions to a tutor. Students enrolled in fully online courses can access this resource directly within their online courses or, beginning in August 2012, through Lone Star's Student Portal. From September 01, 2011 to September 01, 2012, 366 students, who were enrolled in fully online courses, completed 985 tutoring sessions for a total of 561 hours. Of these sessions, 11 percent, or 112 students, completed an exit survey. When asked to rate the tutor, the technology, and whether they would recommend the tutoring service to a friend, respectively, 92.0 percent, 84.8 percent, and 94.6 percent gave a favorable rating.

\section{h. Online New Student Orientation}

Beginning in Spring 2012, all first time in college students (FTIC. were required to take an online orientation and go through an advising and registration session. The online orientation covers general information that ALL new LSCS students need to know. It covers topics such as placement testing, degree options, services, accessing their myLoneStar Portal, Financial Aid, and Next Steps. Once they have completed the online orientation, they are guided to our Orientation webpage where they are asked to select their primary campus in order to sign up for an in-person advising and registration session. FTIC fully online students can select a link to request an appointment with an online adviser.

\section{i. Online Student E- Newsletter}

In an effort to increase communication to fully online students, Online Student Support Services developed an online student newsletter. The newsletter, called the eStudent Times, was launched in June of 2012. It was embedded in an email and sent to the fully online student population of approximately 6,800 students. The newsletter contained information which the Online Student Services unit thought would be pertinent to fully online students, such as: online chat advising, online tutoring, important dates for the semester, and financial aid contact information.

Within this newsletter, Online Student Support Services provided links it thought useful for fully online students, such as, a list of fully online degrees and certificates, technical support contact information, and details about Online Student Support Services. The goal was to communicate with fully online students prior to registration and at the beginning of each for the following semester. After launching this newsletter, Online Student Support Services discussed the effectiveness of its approach and realized that it needed a better process for evaluating the student newsletter.

Consequently, for its second newsletter, Online Student Support Services determined it would track how many students were actually accessing the newsletter as well as specific topics on it, so it could use these data to shape future newsletters to make them more relevant. Consequently, the unit purchased a commercial product called Constant Contact, which allowed it the ability to personalize each e-mail (i.e., it was addressed to the individual and used their first name in the introduction., and assist in tracking the number of students who opened the email as well as the number of students who clicked on particular topics within the newsletter. This would help Online Student Support Services better understand students' interests in specific topics, and plan accordingly. Using Constant Contact, the second newsletter was sent out in September of 2012 to all 7,249 fully online students. The report showed that 10.8 percent of these e-mails were opened, and of those 34.7 percent clicked on topics within the newsletter. The report also identified the most accessed topics. Using this information, Online Student Support Services plans to change the sequence of topics, eliminated the least accessed topics and introduce topics which may be of more interest. In addition, the unit is soliciting participation from online students to serve on an Online Student Advisory Council. The goal of this council will be to provide direction, scope and 
Developing and Implementing Comprehensive Student Support Services for Online Students

continual input and feedback on the Newsletter and other related initiatives to ensure they are meeting their expectations and needs.

\section{CONCLUSION}

At the launch of the third unit in Lone Star College-Online in the spring of 2011, Online Student Support Services had two goals: 1 . to provide at least comparable services to online students that face-to-face students received; and 2. to increase completion and success rates for online students in order to make them comparable to the face-to-face student population. In terms of its first goal, in the spring of 2011 the unit had one manager, and two full-time advisers. By the summer of 2012, due to increasing online student demand, the unit hired an additional seven part-time advisers. During the Fall term of 2012, one additional full time adviser was hired. While Online Student Support Services initially offered services online five days a week in the Fall term of 2011, by spring 2012, due to increased demand, it expanded its service hours by 53 percent increasing its availability in the evenings and offering services seven days a week. In fact, online advising hours averaged 15 hours more per week than what face-to-face students had access to through their campus advisers. The unit now faces the unanticipated issue of face-to-face students requesting access to online advisers due to the efficiency of the model and extended service hours. This provides further evidence that the unit has met and even exceeded its first goal.

In terms of its second goal, the unit will be examining completion and success rates at the end of the Fall term of 2012, and comparing it with the Fall 2011 rates. Although it would not be possible to establish a causal relationship between the unit's initiatives and completion and success rates, it is hoped the combination of initiatives would have an overall positive impact.

Through this process, the unit is gaining a better understanding of how the initiatives and services help support and promote online students. The initiatives are considered a "work-in-progress" and are continually evaluated and examined for ways to improve their utility and efficacy for online students. Lastly, the Online Student Support Services unit is constantly striving to find other innovative methods of addressing and supporting the needs of online students at Lone Star College System.

\section{ABOUT THE AUTHORS}

Marwin Britto currently serves as the Executive Director of Lone Star College-Online at Lone Star College System. In addition, he has served in a number of administrative positions in higher education, and has had 10 years of university experience as a fulltime faculty member. He has published and presented widely in academic journals and conferences in the areas of distance education/online learning, teaching and learning, teacher education, instructional technology, library science and change management. He holds four graduate degrees including a Ph.D. in Instructional Technology from the University of Georgia.

Susan Rush is the Manager of Online Student Support Services at Lone Star College System. Susan has over 20 years of Student Services experience in higher education. She has a Bachelor's degree in Psychology from Sam Houston State University and a Master's degree in Educational/Counseling Psychology from Texas A\&M University. She has worked as a counselor/adviser for 16 years and during those years, developed Career Centers at three community colleges. For the last five years she has worked at Lone Star College's System Office where she implemented multiple system-wide initiatives. Most recently, Susan has moved to Lone Star College's Online department to implement a comprehensive Online Student Support Services department to focus on providing support to Lone Star College's online students.

\section{REFERENCES}

1. Allen, I., and Seaman, J. Going the Distance: Online Education in the USA 2011. Wellesley MA: Babson Survey Research Group, 2011. 
2. Carr, S. As Distance Education Comes of Age, the Challenge Is Keeping the Students. Chronicle of Higher Education, 46(23). pA39-A41 (2000).

3. Diaz, D., \& Cartnal, R. Term length as an indicator of attrition in online learning. Innovate: Journal of Online Education, 2(6). (2006).

4. Simpson, O. The impact on retention of interventions to support distance learning students. Open Learning, 19(1). 79-95 (2004).

5. Pierrakeas, C., Xenos, M., Panagiotakopoulos, C., \& Vergidis, D. A comparative study of dropout rates and causes for two different distance education courses. International Review of Research in Open and Distance Learning, 5(2). (2004).

6. Stanford-Bowers, D. E. Persistence in online classes: A study of perceptions among community college stakeholders. MERLOT Journal of Online Learning and Teaching, 4(1). (2008). http://jolt.merlot.org/vol4no1/stanford-bowers0308.pdf

7. Wojciechowski, A., \& Palmer, L. B. Individual student characteristics: Can any be predictors of success in online classes? Online Journal of Distance Learning Administration, 8(2). (2005). http://www.westga.edu/\%7Edistance/ojdla/summer82/wojciechowski82.htm

8. Cohen, A. M., and Brawer, F. B. The American community college. (4 ${ }^{\text {th }}$ ed.) San Francisco: Jossey-Bass, 2003.

9. Wild, L., \& Ebbers, L. Rethinking student retention in community college. Community College Journal of Research and Practice, 503-513, (2002). http://www.cfder.org/uploads/3/0/4/9/3049955/rethinking_student retention in community colleg es.pdf

10. Crawford, L. "Extended opportunity programs and services for community college retention" Paper presented at the Annual California Community Colleges Chancellor's Office Statewide Conference, Monterey, CA. (1999, March) (ERIC Document Reproduction Service No. ED 429 642).

11. Star Newsletter. Star Newsletter 2012, a Lone Star College System Publication. (2012).

12. Council for Higher Education Accreditation Accreditation and assuring quality in distance learning. CHEA Institute for Research and Study of Accreditation and Quality Assurance. CHEA Monograph Series, Number 1, 2002.

13. Long, P., Tricker, T., Rangecroft, M. \& Gilroy, P. Measuring the satisfaction gap: education in the marketplace. Total Quality Management, 10, S722-S778, (1999).

14. Perez, E. Online Community College Students more likely to fail, withdraw. (2011). http://californiawatch.org/dailyreport/online-community-college-students-more-likely-failwithdraw-11581

15. Ali, R., \& Leeds, E. M. The Impact of Face-to-Face Orientation on Online Retention: A Pilot Study. Online Journal of Distance Learning Administration, 12(4). (2009).

16. Patterson, B., \& McFadden, C. Attrition in online and campus degree programs. Online Journal of Distance Learning Administration, 12 (2). (2009).

http://www.westga.edu/ distance/ojdla/summer122/patterson112.html

17. Noel-Levitz national online learners priorities report. (2010). Retrieved from https://www.noellevitz.com/Our+Services/Retention/Tools/Priorities+Survey+for+Online+Learners /

18. Yukseltruk, E., \& Inan, F. A. Examining the factors affecting student dropout in an online learning environment. ASHE-ERIC Higher Education Report (ERIC No. ED 494345 (2006).

19. Moore, K., Bartkovich, J., Fetzner, M., \& Ison, S. Success in cyberspace: Student retention in online courses. AIR 2002 forum paper. (2002). 
http://search.ebscohost.com.proxy.lib.pdx.edu/login.aspx?direct=true\&db=eric\&AN=ED472473\&si te=ehost-live

20. Dietz-Uhler, B., Fisher, A., \& Han, A. Designing courses to promote student retention. Journal of Educational Technology Systems, 36(1), 105-112, (2008).

21. Heyman, E. Overcoming student retention issues in higher education online programs. Online Journal of Distance Learning Administration, 8(4) (2010). http://www.westga.edu/ distance/ojdla/winter134/heyman134.html.

22. Dahl, J. Strategies for 100 percent retention: Feedback, interaction. Distance Education Report, 8(16) 1-6, (2004).

23. Lorenzetti, J. Developing Effective Online Student Services, Distance Education Report, 10(4) p1$2,(2006)$.

24. Dinov, I. D., Sanchez, J., \& Christou, N. Pedagogical utilization and assessment of the statistic online computational resource in introductory probability and statistics courses. Computers and Education, 50(1) 284-300 (2008).

25. Fisher, M., \& Baird, D. E. Online learning design that fosters student support, self-regulation, and retention. Campus-Wide Information Systems, 22(2) 88-107 (2005).

26. Bauman, P. Student Retention: What You Can Control, \& How. Distance Education Report, 6(16) (2002).

27. Scagnoli, N. Students orientation for online programs. Journal of Research on Technology in Education, 34(1) 19-27 (2001).

28. Veenstra, C. P. A strategy for improving freshman college retention. Journal for Quality and Participation, 31(4) 19-23 (2009).

29. Herbert, M. Staying the course: A study in online student satisfaction and retention. Online Journal of Distance Learning Administration, 10(1). (2007). http://www.westga.edu/\%7Edistance/ojdla/winter94/ herbert94.htm

30. Higher Learning Commission. Restructured expectations: A transitional workbook. Chicago, 2003.

31. Chyung, S.Y. Systematic and systemic approaches to reducing attrition rates in online higher education. American Journal of Distance Education 15(3) 36-49 (2001).

32. Scalese, E. R. What can a college distance education program do to increase persistence and decrease attrition? Journal of Instruction Delivery Systems 15(3) 16-20 (2001).

33. Paloff, R. \& Pratt, K. The virtual student: A profile and guide to working with online learners. San Francisco: Jossey-Bass, 2003.

34. Ozoglu, M. Assessment of learner support services in the Turkish open education system. International Journal of Instructional Technology and Distance Learning, 7(11) (2010).

35. Harrell, I.L. Increasing the Success of Online Students. (2008). http://www.vccaedu.org/inquiry/inquiry-spring-2008/1-13-Harrell.html

36. Kelso, M.G. Mandatory online orientation courses for online learners. (2011). http://papers.ssrn.com/sol3/papers.cfm?abstract_id=1797290

37. Crawley, A. Supporting Online Students. A Guide to Planning, Implementing and Evaluating Services. Jossey-Bass: San Francisco, 2012.

38. Mercer, R., \& Simmons, M. Using Learner Readiness to Improve Student Retention. Deatsville, AL: SmarterServices, LLC. (2010).

39. Feldberg, J. Five help desk tips to increase retention rates, learner satisfaction and revenues. Distance Education Report 5, 20, 1-2 (2001).

40. Murray, B. What makes students stay. (2001). 
http://elearnmag.org/subpage/sub_page.cfm?article_pk=1301\&page_number_nb=1\&title=FEATUR E\%20STORY

41. Lorenzetti, J. P. Before They Drift Away: Two Experts Pool Retention Insights. Distance Education Report, 6(8) (2002).

42. Green, K.C. Managing Online Education Survey. (2010). http://wcet.wiche.edu/wcet/docs/moe/ManagingOnlineEd2010-ExecSummaryGraphics.pdf

43. Nitsch, W.B. Student Retention in Online Graduation Education. (2003). http://www.decadeconsulting.com/decade/papers/StudentRetention.pdf

44. California Community Colleges. (2011). Distance Education Report. http://californiacommunitycolleges.cccco.edu/Portals/0/reportsTB/DistanceEducation2011_final.pdf

45. Xu, D., \& Jaggars, S.S. Online and hybrid course enrollment and performance in Washington State Community and Technical Colleges. CCRC (2011). Working Paper No. 31. New York: Community College Research Center, Columbia University.

46. Pulsinelli, O. Lone Star College Breaks Record Enrollment. Houston Business Journal, September 18, 2012. http://www.bizjournals.com/houston/morning_call/2012/09/lone-star-college-systembreaks.html

47. Instructional Technology Council. (2012). 2011 Distance Education Survey Results. Trends in eLearning: Tracking the Impact of eLearning at Community. http://www.itcnetwork.org/attachments/article/87/ITCAnnualSurveyMarch2012.pdf

48. Dziuban, C., \& Moskal, P. The Distributed Learning Impact Evaluation, An Ongoing Longitudinal Study at the University of Central Florida. (2010). [PowerPoint presentation.] http://cdl.ucf.edu/research/rite/presentations/

49. MarylandOnline. (2008). Quality matters rubric standards 2008-2010 edition with assigned point values. https://www.qmprogram.org/rubric 